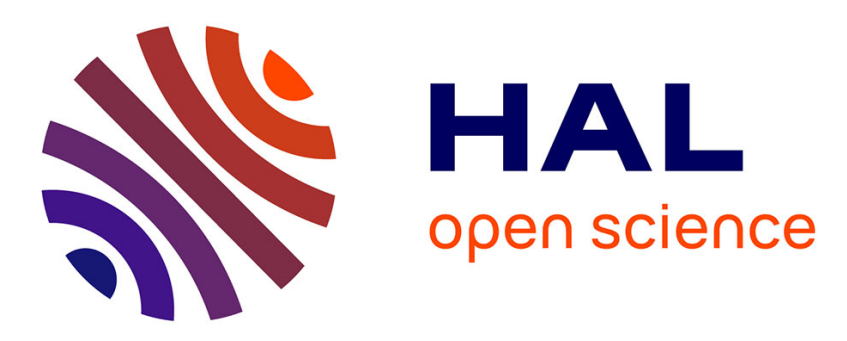

\title{
Vulnerability of marine habitats to the invasive green alga Caulerpa racemosa var. cylindracea within a marine protected area
}

Stelios Katsanevakis, Yiannis Issaris, Dimitris Poursanidis, Maria

Thessalou-Legaki

\section{To cite this version:}

Stelios Katsanevakis, Yiannis Issaris, Dimitris Poursanidis, Maria Thessalou-Legaki. Vulnerability of marine habitats to the invasive green alga Caulerpa racemosa var. cylindracea within a marine protected area. Marine Environmental Research, 2010, 70 (2), pp.210. 10.1016/j.marenvres.2010.05.003 . hal-00602594

\section{HAL Id: hal-00602594 \\ https://hal.science/hal-00602594}

Submitted on 23 Jun 2011

HAL is a multi-disciplinary open access archive for the deposit and dissemination of scientific research documents, whether they are published or not. The documents may come from teaching and research institutions in France or abroad, or from public or private research centers.
L'archive ouverte pluridisciplinaire HAL, est destinée au dépôt et à la diffusion de documents scientifiques de niveau recherche, publiés ou non, émanant des établissements d'enseignement et de recherche français ou étrangers, des laboratoires publics ou privés. 


\section{Accepted Manuscript}

Title: Vulnerability of marine habitats to the invasive green alga Caulerpa racemosa var. cylindracea within a marine protected area

Authors: Stelios Katsanevakis, Yiannis Issaris, Dimitris Poursanidis, Maria ThessalouLegaki

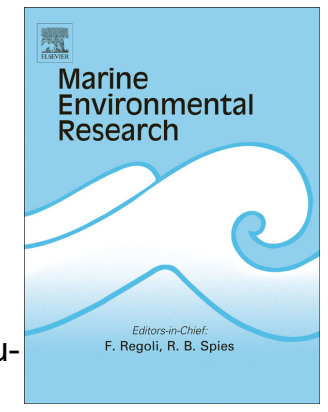

PII:

S0141-1136(10)00070-X

DOI:

10.1016/j.marenvres.2010.05.003

Reference: MERE 3450

To appear in: Marine Environmental Research

Received Date: 12 March 2010

Revised Date: 6 May 2010

Accepted Date: 7 May 2010

Please cite this article as: Katsanevakis, S., Issaris, Y., Poursanidis, D., Thessalou-Legaki, M.

Vulnerability of marine habitats to the invasive green alga Caulerpa racemosa var. cylindracea within a marine protected area, Marine Environmental Research (2010), doi: 10.1016/j.marenvres.2010.05.003

This is a PDF file of an unedited manuscript that has been accepted for publication. As a service to our customers we are providing this early version of the manuscript. The manuscript will undergo copyediting, typesetting, and review of the resulting proof before it is published in its final form. Please note that during the production process errors may be discovered which could affect the content, and all legal disclaimers that apply to the journal pertain. 
1 Vulnerability of marine habitats to the invasive green alga Caulerpa racemosa

2 var. cylindracea within a marine protected area

3

4

5

6 Stelios Katsanevakis ${ }^{\mathrm{a}^{*}}$, Yiannis Issaris $^{\mathrm{a}, \mathrm{b}}$, Dimitris Poursanidis ${ }^{\mathrm{c}, \mathrm{d}}$, Maria Thessalou-

$7 \quad$ Legaki $^{\mathrm{b}}$

8

9

10 a Institute of Marine Biological Resources, Hellenic Centre for Marine Research,

11 Anavyssos 19013, Greece

$12{ }^{\mathrm{b}}$ Department of Zoology-Marine Biology, School of Biology, University of Athens,

13 Panepistimioupolis, 15784 Athens, Greece

$14{ }^{\mathrm{c}}$ WWF Hellas, Glaukou 13, 71409 Knossos, Heraklion, Greece

$15{ }^{\mathrm{d}}$ Department of Marine Sciences, University of the Aegean, Mytilene, 81100, Greece

16

$17 *$ Corresponding author (tel: +30 2109856701, fax: +30 2109811713)

18 Emails:

19 SK: stelios@katsanevakis.com

20 YI: yissaris@gmail.com

21 DP: dpoursanidis@gmail.com

22 MT-L: mthessal@biol.uoa.gr 


\section{Abstract}

25 The relative vulnerability of various habitat types to Caulerpa racemosa var.

26 cylindracea invasion was investigated in the National Marine Park of Zakynthos

27 (Ionian Sea, Greece). The density of C. racemosa fronds was modelled with

28 generalized additive models for location, scale and shape (GAMLSS), based on an

29 information theory approach. The species was present in as much as $33 \%$ of 748

30 randomly placed quadrats, which documents its aggressive establishment in the area.

31 The probability of presence of the alga within randomly placed $20 \times 20 \mathrm{~cm}$ quadrats

32 was $83 \%$ on 'matte morte' (zones of fibrous remnants of a former P. oceanica bed),

$3369 \%$ on rocky bottoms, $86 \%$ along the margins of Posidonia oceanica meadows, $10 \%$

34 on sandy/muddy substrates, and $6 \%$ within $P$. oceanica meadows. The high frond

35 density on 'matte morte' and rocky bottoms indicates their high vulnerability. The

36 lowest frond density was observed within P. oceanica meadows. However, on the

37 margins of $P$. oceanica meadows and within gaps in fragmented meadows relative

38 high C. racemosa densities were observed. Such gaps within meadows represent spots

39 of high vulnerability to C. racemosa invasion.

40

41 Key words: benthic ecology; biological pollutants; Caulerpa racemosa; invasive

42 macrophytes; phytobenthos; seagrass; vulnerability; Mediterranean; MPA; Greece 
45

46

47

\section{Introduction}

More than 900 introduced species have been reported so far from the Mediterranean Sea, of which $\sim 500$ are considered as established. Among them, there are more than 100 established alien macrophytes (Zenetos et al., 2008). Approximately one tenth of these species can be considered as invasive, i.e. they have overcome biotic and abiotic barriers, are able to disseminate away from their area of initial introduction, and have a noticeable ecological and economic impact. Decline of biodiversity, effects on phytobenthic, fish and invertebrate biota, threat to the ecological stability of invaded ecosystems, and pressures on economic activities are among the impacts of invasive macrophytes (Boudouresque and Verlaque, 2002; Zenetos et al., 2006; Schaffelke and Hewitt, 2007; Piazzi and Balata, 2009).

\section{The green alga Caulerpa racemosa (Forsskål) J. Agardh sensu lato (Chlorophyta:} Bryopsidales) is widely distributed in tropical and warm temperate seas (Verlaque et al. 2003). Three intraspecific taxa of C. racemosa have been identified in the Mediterranean Sea, among which C. racemosa var. cylindracea (Sonder) Verlaque, Huisman, and Boudouresque (Verlaque et al., 2003; Klein and Verlaque, 2008) (hereafter C. racemosa) is one of the most aggressive invaders in the basin (Streftaris and Zenetos, 2006; Verlaque et al., 2004; Klein and Verlaque, 2008). This variety was first found in the Mediterranean Sea along the Libyan coast in 1990 (Nizamuddin, 1991), being introduced from south-western Australia (Famà et al., 2000; Verlaque et al., 2003). It has rapidly spread throughout the entire basin, reaching as far as the Canary Islands in the Eastern Atlantic Ocean (Verlaque et al., 2004). The species has been reported from all kind of substrata with a variety of benthic assemblages, 
70 between 0 and $70 \mathrm{~m}$ depth, in both polluted and unpolluted areas, and has

71 demonstrated an excessive rate of proliferation and high adaptability to physical

72 stressors (Piazzi et al., 2005; Streftaris and Zenetos, 2006; Klein and Verlaque, 2008;

73 Tsiamis et al., 2008). Its stolons can quickly elongate and easily overgrow other

74 macroalgal (Piazzi et al., 2001; Piazzi and Ceccherelli, 2006) or invertebrate species

75 (Kružić et al., 2008; Baldacconi and Corriero, 2009). Quite often C. racemosa forms

76 compact meadows in the Mediterranean Sea (Argyrou et al., 1999; Ruitton et al.,

77 2005; Klein and Verlaque, 2008; Katsanevakis and Thessalou-Legaki, 2009), contrary

78 to its native range in south-western Australia, where it does not form monospecific

79 stands but grows intermixed with other algae (Verlaque et al., 2003). It has a high

80 potential for dispersal by fragmentation and re-establishment of stolons (Ceccherelli

81 and Piazzi, 2001), formation of propagules (Renoncourt and Meinesz, 2002), and

82 sexual reproduction (Panayotidis and Žuljević, 2001).

C. racemosa was initially reported in Greece from Zakynthos Island and Pylos Bay

85

86

87

88 (Ionian Sea) in 1993 (Panayotidis and Montesanto, 1994). Since then, the species has been spreading extremely rapidly along Greek coasts and it is now found on the majority of the Greek coastal areas (Tsiamis et al., 2010; Salomidi et al., 2009).

\section{There are a few studies in the literature comparing invasion success of $C$. racemosa} on different substrates such as varying shoot densities of Posidonia oceanica (L.)

Delile meadows (Ceccherelli et al., 2000) or different types (encrusting, filamentous, and erect) of vegetation layers (Ceccherelli et al., 2002). However, the extent to which biotic and abiotic interactions influence the spread of the alga is not fully understood, although there are some relevant efforts (e.g., Bulleri and Benedetti-Cecchi, 2008). So 
95 far, there is no comparative study investigating the relative vulnerability of the main

96 Mediterranean habitat types to C. racemosa invasion. To provide such insight, in the

97 present study we investigated the relative vulnerability of a variety of habitat types to

98 C. racemosa, in one of the sites of its first appearance in the early 90's (Laganas Bay,

99 Zakynthos Island, Ionian Sea). Special focus was given on various substrate types

100 within fragmented Posidonia oceanica meadows. Hereafter, vulnerability is defined

101 as the susceptibility to the introduction, establishment and spatial spread of the

102 invader, i.e. how easily it may attain high densities.

103

104 Until lately Marine Protected Areas (MPAs) were established to protect biodiversity

105 via the complete removal of human exploitation and other activities, and thus were

106 intended to be "islands" of nature and tranquility in a sea of hostile environment

107 (Simberloff 2000; Boudouresque et al. 2005). However, in many cases MPAs have

108 not been able to stop or limit the expansion of invasive alien species. For example, the

109 boundaries of many northwestern Mediterranean marine parks offered no protection

110 to the invasion of the green alga Caulerpa taxifolia, once it was present along

111 neighboring coasts (Meinesz 1999). International shipping is usually prohibited in

112 MPAs but recreational or small fishing boats could equally well be the vectors of

113 alien species introductions. Indeed an assessment of the importance of recreational

114 boating carried out in 100 yachts in Scotland has confirmed that boating must be

115 considered as a high risk vector for non-native species (Ashton et al. 2006). The

116 spreading of both Caulerpa racemosa and C. taxifolia in the western Mediterranean

117 was facilitated by fishing activity, in particular by bottom trawlers and trammel nets

118 (Relini et al. 2000; Magri et al 2001). Restrictive measures on the activities of

119 recreational and fishing boats within MPAs might have a positive effect by 
120 decelerating the invasion rates of some alien macrophytes. Another aim of this study

121 was to investigate whether protection measures within an MPA (the National Marine

122 Park of Zakynthos) had any effect on C. racemosa spread.

123

124 Specifically, we tested the following hypotheses:

125 1. Various habitat types have different vulnerability to the invasive alga $C$.

126 racemosa.

127 2. Within fragmented Posidonia oceanica meadows vulnerability differs among

128 structural substrate types such as the meadow margin and gaps of various sizes

129 without alive P. oceanica.

1303 3. Protection measures in MPAs, especially restrictions on recreational boating

131 and fishing activities, effectively restrain the expansion of $C$. racemosa.

132 For all the points above we aimed to quantify the potential differences among

133 habitats/substrate types and management zones by appropriately modelling the

134 frond density of C. racemosa.

135

136

137 2. Materials and Methods

138

1392.1 Study area

140

141 The survey was conducted in the National Marine Park of Zakynthos (NMPZ) (Fig.

142 1). The bay of Laganas in Zakynthos Isl. hosts the most important known nesting

143 aggregation of the endangered loggerhead sea turtle, Caretta caretta (Linnaeus, 
144 1758), in the Mediterranean. NMPZ was founded in 1999, with the protection of the

145 critical nesting habitat of the loggerhead sea turtle being its main objective.

146

147 Within the marine area of the NMPZ there are three main management zones (A, B,

148 C) in Laganas Bay and a buffer zone (Ia) (Fig. 1). In Zone A no recreational boat

149 activity is allowed, in Zone B boats are allowed to enter with a speed limit of 6 knots

150 but anchoring is forbidden, and in Zone $\mathrm{C}$ boats are allowed to travel with a speed

151 limit of 6 knots and also to anchor. Commercial fishing using mobile gear and

152 recreational fishing is prohibited in all zones (including the buffer zone) and

153 commercial fishing using static gears is prohibited in Zone A from the beginning of

154 May until the end of October. The management zones do not conform to some

155 specific features of the marine environment, but they were established almost

156 exclusively on criteria regarding undisturbed approach of turtles to the nesting

157 beaches. The three management zones and the buffer zone provide a quasi-

158 experimental setting of varying level of protection (from very low in Ia to high in

159 zone A), which was exploited in this study to test our third hypothesis.

160

$161 \quad 2.2$ Field work

162

163 Field work was conducted during the first fortnight of October 2009. Two

164 independent surveys were conducted. The aim of the first survey was to assess

165 vulnerability of all main habitat types of the survey area, while the second survey

166 focused on Posidonia oceanica beds, specifically on the relative vulnerability of

167 different substrate types within fragmented meadows. Fragmented meadows are

168 defined as those where the continuity of the meadow is interrupted by gaps of various 
169 sizes without alive $P$. oceanica (mentioned as 'patches' hereafter), which could be

170 either sandy or 'matte morte' areas, i.e. zones of fibrous remnants (dead rhizomes) of

171 a former P. oceanica bed.

172

173 In the first survey, three 50-m line transects were surveyed with SCUBA diving in

174 each of 23 sites. The selection of the 23 sites was based on the following

175 requirements: (1) good spatial coverage of the study area; (2) representative samples

176 on all major habitat types of the study area; (3) narrow range of surveyed depths. The

177 latter requirement was to avoid adding depth as an extra covariate, as there is an

178 important bathymetry-related variation of C. racemosa density (Salomidi et al., 2009),

179 and also for logistical reasons for diving. Thus, all measurements were conducted at

180 depths between 5 and $13 \mathrm{~m}$. The above restrictions caused a non-uniform spatial

181 distribution of the sampling sites in the study area. Specifically, the central regions of

182 zones B and Ia were not sampled as they were generally deep (reaching $70 \mathrm{~m}$ in zone

183 Ia), while the shallow regions (north part of zone B) had exclusively sandy bottoms

184 (all other habitat/substrate types were absent).

185

186 The line transects were defined with a nylon line, marked with water-resistant

187 numbered signs every five meters, that was deployed using a diving reel. After

188 deploying each line transect, the number of C. racemosa fronds within a $20 \times 20 \mathrm{~cm}$

189 quadrat was counted at each sign, i.e. eleven measurements were conducted along

190 each line. For each quadrat, the habitat type was also logged. Five different habitat

191 types were identified: unvegetated sandy bottoms (S); Posidonia oceanica meadows

192 (PO); 'matte morte' (MM); margins of P. oceanica meadows, usually with sandy 
193 bottoms or 'matte morte' (PM); and rocky bottoms (R). Although, PM is strictly not a

194 separate 'habitat type' than PO, we catachrestically use this terminology hereafter.

195

196 In the second survey, the number of C. racemosa fronds within $20 \times 20 \mathrm{~cm}$ quadrats

197 was measured in a total of 44 patches distributed in 11 sites (Fig. 1), where

198 fragmented P. oceanica meadows was the dominant ecotope. In each site, a 200-m

199 line was deployed defining a straight line transect. When the line crossed a patch,

200 frond measurements were conducted in six locations along the line, representing three

201 different substrate types: at the two intersections of the patch margin and the line

202 (PM), within the $P$. oceanica meadow at a $2 \mathrm{~m}$ distance from the margin of the patch

203 (PO), and in two randomly chosen spots within the patch (Pa) (Fig. 2). The size of the

204 patch, defined as its maximum dimension (in m), was also recorded.

205

\subsection{Modelling frond counts}

207

208 Some distinctive features of data collected on the abundance of organisms (count

209 data) are: (i) the tendency to contain many zero values (zero-inflated dataset); (ii)

210 overdispersion, defined as the extra variation, which is not explained by the Poisson

211 distribution alone; (iii) heterogeneity of variances (where the variance of the

212 distribution of the response variable changes with explanatory variables). Failure to

213 account for these issues will cause bias in parameter estimations and the associated

214 measures of uncertainty, can reduce the capability to detect relationships, or even lead

215 to incorrect inference (Martin et al., 2005; Stasinopoulos and Rigby, 2007). 
217 Herein, generalized additive models for location, scale and shape (GAMLSS; Rigby

218 and Stasinopoulos, 2005) were applied to effectively confront the abovementioned

219 issues. GAMLSS are regression type models that overcome many of the limitations

220 associated with the popular generalized linear models (GLM; McCullagh and Nedler,

221 1989) and generalized additive models (GAM; Hastie and Tibshirani, 1990). In

222 GAMLSS the exponential family distribution assumption for the response variable is

223 relaxed and replaced by a general distribution family, and the systematic part of the

224 model is expanded to allow modelling not only of the mean (or location) but also

225 other parameters of the distribution (Stasinopoulos and Rigby, 2007). For fitting the

226 models, the gamlss package (Stasinopoulos and Rigby, 2007) was used in R v.2.8.0

227 (R Development Core Team 2008).

229 Inference was based on the information theory approach (Burnham and Anderson,

230 2002), i.e. an integrated process of a priori specification of a set of candidate models,

231 model selection based on the principle of parsimony according to Akaike's

232 information criterion (AIC; Akaike, 1973), and the estimation of parameters and their 233 precision.

235 For data collected in the first survey, two categorical variables, habitat type (habitat) 236 and the corresponding management zone of the NMPZ (zone) were used as potential 237 predictor variables of the C. racemosa frond counts. Seven different GAMLSS, $g_{i}, i=$ 2380 to 6 , were fitted (Table 1). Either only the mean response (models $g_{1}-g_{3}$ ) or both the 239 mean response and the standard deviation (models $g_{4}-g_{6}$ ) were modelled, with one or 240 both predictor variables, i.e. in models $g_{1}-g_{3}$ the standard deviation was assumed 
241 constant, while in $g_{4}-g_{6}$ dependent on the predictor variables. Model $g_{0}$ was the null

242 model, with no predictor variable, while $g_{6}$ was the full model.

244 To identify the best underlying distribution of the response variable, six potential

245 distributions were compared: Poisson, negative binomial (Anscombe, 1950), zero-

246 inflated Poisson (Lambert, 1992), Poisson-inverse Gaussian (Dean et al., 1989),

247 Sichel (Rigby et al., 2008), and Delaporte (Rigby et al., 2008). Comparisons among

248 different error distributions were based on the full model $\left(g_{6}\right)$, and selection was based 249 on AIC.

251 The AIC differences, $\Delta_{i}=\mathrm{AIC}_{\mathrm{i}}-\mathrm{AIC}_{\min }$, were computed over all candidate models.

252 Models with $\Delta_{\mathrm{i}}>10$ had essentially no support and could be omitted from further 253 consideration, while all models with $\Delta_{\mathrm{i}}<2$ had substantial support (Burnham and 254 Anderson 2002). To quantify the plausibility of each model, given the data and set of 255 six models, the 'Akaike weight' $w_{i}$ of each model was calculated, where $256 w_{i}=\exp \left(-0.5 \Delta_{i}\right) / \sum_{j} \exp \left(-0.5 \Delta_{j}\right)$. The 'Akaike weight' is considered as the weight of 257 evidence in favour of model $i$ being the actual best model of the available set of 258 models (Akaike, 1983; Buckland et al., 1997; Burnham and Anderson, 2002).

259 Estimates of the relative importance of predictor variables $j$ was made by summing 260 the Akaike weights across all the models in the set where each variable occurs $\left[\mathrm{w}_{+}(j)\right]$; 261 the larger the sum of Akaike weights the more important that variable is, relative to 262 the other variables (Burnham and Anderson, 2002).

264 For data collected in patches within P. oceanica meadows (second survey), two 265 potential predictor variables were included in the candidate models, patch size (size), 
266 which was a continuous variable, and the location of the sampled quadrat in the region

267 of the patch (location). Location was a categorical variable with three levels (Pa, PM,

268 and PO) (Fig. 2). Seven different GAMLSS, $h_{i}, i=0$ to 6 , were fitted (Table 2). Either

269 only the mean response (models $h_{1}-h_{3}$ ) or both the mean response and the standard

270 deviation (models $h_{4}-h_{6}$ ) were modelled, with one or both predictor variables. Model

$271 h_{0}$ was the null model, with no predictor variable, while $h_{6}$ was the full model. The

272 same approach as with the data of the first survey was followed for the identification

273 of the best underlying statistical distribution and for model selection.

\section{Results}

\subsection{Vulnerability of habitat types (Survey 1)}

Among the six tested distributions, negative binomial gave the lowest AIC and was

281 selected as the underlying distribution for modeling the counts of $C$. racemosa fronds

282 (Table 3). The Delaporte distribution also had substantial support by the data with

283 only 1.9 units higher AIC score, while all other distributional assumptions were not

284 supported $\left(\Delta_{\mathrm{i}} \gg>10\right)$.

286 The best models of the expected number of $C$. racemosa fronds were $g_{4}\left(w_{4}=49.7 \%\right)$

287 and $g_{6}\left(w_{6}=50.3 \%\right)$ with almost equal support, while all other models had essentially 288 no support $\left(\Delta_{\mathrm{i}}>>10\right)$. The habitat type was more important as predictor variable of $C$.

289 racemosa frond counts $\left[\mathrm{w}_{+}(\right.$habitat $\left.)=1.00\right]$ than zone $\left[\mathrm{w}_{+}(\right.$zone $\left.)=0.50\right]$. Model $g_{4}$ 290 was nested within $g_{6}$ (full model), and their only difference was in the inclusion of 
$291 z$ zone in $g_{6}$. In relation to habitat type (habitat) the output of the two models did not 292 differ, and thus only $g_{6}$ is presented herein (Fig. 3). Models that considered constant 293 variance $\left(g_{0}-g_{3}\right)$ had essentially no support $\left(\Delta_{\mathrm{i}}>>10\right)$ indicating that heterogeneity of

294 variances could not be ignored in our case. As assessed by normal QQ-plots (plots of 295 the quantiles of the normal distribution against the distribution of the residuals), the 296 normalized residuals of model $g_{6}$ behaved well, while in model $g_{3}$, which is the same 297 as $g_{6}$ for the mean response but did not include standard deviation modelling, the 298 residuals deviated from the normal distribution (Figure 4).

300 C. racemosa was found in 245 of the 748 quadrats that were sampled (33\%). The 301 probability of presence within a randomly placed $20 \times 20 \mathrm{~cm}$ quadrat was $83 \%$ in $302 \mathrm{MM}, 69 \%$ in R, $86 \%$ in PM, $10 \%$ in S, and 6\% in PO. The frond density was the 303 highest on matte morte and rocky bottoms (mostly rocky reefs with photophilic 304 macroalgal assemblages, dominated by Cystoseira spp.) and the lowest within $P$. 305 oceanica meadows (Fig. 3; Table 4). C. racemosa was completely absent in 306 unfragmented robust $P$. oceanica beds, and was only recorded in a few spots of low $P$. 307 oceanica density in fragmented meadows. On the margins of $P$. oceanica meadows, 308 intermediate C. racemosa densities were observed. On sandy bottoms C. racemosa 309 density was generally low and highly variable (Fig. 3). Similar values of frond density

310 were observed in the three management zones of the NMPZ (A, B, and C), while a 311 slightly lower mean value was observed in the buffer zone Ia (Fig. 3; Table 4). 
315 Among the six tested distributions, negative binomial gave the lowest AIC and was

316 selected as the underlying distribution for modeling the counts of $C$. racemosa fronds

317 (Table 3). The Delaporte distribution also had substantial support, the Sichel

318 distribution had substantially less support, while all other distributional assumptions

319 were not supported $\left(\Delta_{\mathrm{i}} \gg>10\right)$.

321 The best model of the expected number of $C$. racemosa fronds in the region of

322 patches within P.oceanica meadows was $h_{4}\left(w_{4}=59.6 \%\right)$ (Table 2). Model $h_{6}$ also

323 had substantial support $\left(w_{6}=23.0 \%\right)$, and models $h_{1}$ and $h_{3}$ had essentially less

324 support. The other models were not supported by the data $\left(\Delta_{\mathrm{i}} \gg>10\right)$. Location was

325 more important as a predictor variable of $C$. racemosa frond counts $\left[\mathrm{w}_{+}(\right.$location $)=$

326 1.00] than patch size $\left[\mathrm{w}_{+}(\right.$size $\left.)=0.33\right]$. Only model $h_{4}$ is presented herein; in $h_{6}$ size

327 was included as an additional variable but it was not significant either for the mean (p

$328=0.22)$ or for the standard deviation $(\mathrm{p}=0.72)$, thus $h_{6}$ did not provide any additional

329 information and was not investigated further. Models that assumed constant variance

$330 \quad\left(g_{0}-g_{3}\right)$ had less support $\left[\mathrm{w}_{+}\left(g_{0}-g_{3}\right)=17.4 \%\right]$ than models assuming heterogeneous

331 variances $\left[\mathrm{w}_{+}\left(g_{4}-g_{6}\right)=82.6 \%\right]$. Model $h_{4}$ provided a good absolute fit, as assessed by

332 the Q-Q plot and the distribution of normalized residuals.

334 C. racemosa was present in $50 \%$ of the quadrats in $\mathrm{PM}, 19.3 \%$ of those in $\mathrm{Pa}$, and

335 only $4.5 \%$ of those in PO. The frequency of presence of the alga in PM was

336 significantly higher than the frequency of presence in $\mathrm{Pa}$ (chi-square test, $\mathrm{p}<0.001$ ).

337 The frond density in $\mathrm{Pa}(2.0-8.5$ fronds in $20 \times 20 \mathrm{~cm}$ quadrats; $95 \% \mathrm{CI})$ was not

338 significantly different $(\mathrm{p}=0.19)$ than the frond density in PM (4.7-11.3 fronds) but

339 was significantly higher $(\mathrm{p}<0.001)$ than the frond density in PO $(0.03-0.32$ fronds $)$ 
340 (Fig. 5). Conditional on presence, the counts of $C$. racemosa fronds did not differ

341 between Pa (7.8-12.9 fronds) and PM (9.4-13.3 fronds) but were significantly lower

342 in PO (1.1-3.3 fronds) (95\% Tukey test, based on log-transformed counts to

343 homogenize variances).

\section{Discussion}

The habitat types investigated were found to have markedly different vulnerabilities to the Caulerpa racemosa invasion. The highest frond densities were observed in matte morte and rocky habitat types, indicating their high vulnerability. On sandy/muddy

351 bottoms the frond density was substantially lower indicating lower vulnerability of

352 this habitat type, especially in unstable soft substrata. Similar qualitative observations

353 have been reported elsewhere, e.g. at Marseilles, dense C. racemosa meadows have

354 colonized matte morte areas and coarse sediment but the sandy bottoms were only

355 poorly colonized by few stolons (Ruitton et al., 2005). Under certain conditions, $C$.

356 racemosa may form compact dense mats on soft bottoms but such mats seem to

357 mostly occur in matte morte zones (Argyrou et al., 1999; Ruitton et al., 2005) or areas

358 where native meadows pre-existed, e.g. in Caulerpa prolifera beds (S.K., pers. obs.),

359 and not in previously unvegetated sandy/muddy bottoms.

361 Probability of C. racemosa presence in P. oceanica meadows was low and the alga

362 was mostly restricted in the narrow margins of the seagrass meadows and in gaps

363 within fragmented meadows. As demonstrated by this study, C. racemosa average

364 density was high in the meadow margins and in patches, while it abruptly declined to 
365 practically zero within the meadow at a short distance from the margin. Thus, in

366 fragmented seagrass meadows, the sandy or matte morte patches represent the spots of

367 high vulnerability to C. racemosa invasion. As indicated by the significantly higher

368 probability of C. racemosa presence in PM than in Pa locations, the margins of

369 patches represent the preferable location within a fragmented meadow for the

370 successful establishment of the alga. Other studies have indicated that both the

371 vertical and horizontal algal growth is negatively influenced by seagrass density, and

372 dense and healthy $P$. oceanica meadows represent a barrier to the colonization of $C$.

373 racemosa (Ceccherelli et al., 2000; Klein and Verlaque, 2008).

375 The above results seem to be partly due to the dispersal mechanism of the species by 376 fragmentation, which is one of the main reasons for the fast spread of $C$. racemosa in 377 the Mediterranean. Fragments of the species, produced by either natural or 378 anthropogenic (fishing gear, anchoring) processes, have to stabilize for some time on 379 the substrate in order to get firmly anchored with their rhizoids and become resistant 380 to hydrodynamic forces. Once anchored, the stolons will elongate and the clone will 381 quickly expand locally. Matte morte, rocky habitats, and the margins of P. oceanica 382 meadows provide appropriate substrates with many overhangs and other spots of easy 383 attachment of algal fragments, contrary to sandy/muddy substrates. For example, 384 fragments drifting by waves or currents will easily be brought to a halt when they 385 reach the margin of a sea grass meadow as they will get entangled to sea grass 386 rhizomes or leaves. Similarly, on sandy/muddy bottoms it is not uncommon to 387 observe C. racemosa fragments attached to small 'hard' objects such as marine litter 388 or sponge colonies, while the alga is completely absent from everywhere else in the 389 surrounding soft bottom (SK, pers. obs.). Such hard objects probably act as anchoring 
390 points of drifting $C$. racemosa fragments. We assume that this mechanism of

391 attachment of algal fragments is the cause of a substantial part of the variation of $C$.

392 racemosa frond density among habitat/substrate types.

394 In seagrass beds that are not in a good state (high fragmentation, large areas of matte 395 morte, low shoot density) vulnerability to C. racemosa invasion would be higher.

396 Scars created by anchoring in seagrass beds will also favour the distributional

397 expansion of the alga. It has been demonstrated that boat anchoring has a destructive

398 impact on seagrass meadows destroying many shoots and creating scars that can take

399 a long-time to be re-colonized, especially in meadows of slow growth seagrass species

400 such as P. oceanica (Francour et al., 1999; Milazzo et al., 2004; Ceccherelli et al.,

401 2007; Montefalcone et al., 2008). Thus, anchoring in P. oceanica beds creates

402 favourable microhabitats for the settlement and expansion of C. racemosa. In this

403 respect, a ban of anchoring in seagrass beds, apart from being a management measure

404 for the protection of the meadow, is a measure against the further distributional

405 expansion of C. racemosa.

406

407 Fishing, especially with mobile gears, such as otter trawls and boat seines, but also

408 with trammel nets, substantially contributes to the spread of Caulerpa spp (Relini et

409 al. 2000; Magri et al 2001). Fragments of the species are collected by fishing gear and

410 then discarded by fishermen together with all by-catch and debris, sometimes far from

411 the fishing site. In a similar way recreational boats may assist the dispersion of $C$.

412 racemosa by fragmenting its stolons during anchoring and even transferring such

413 fragments to the surface seawater layers from where longer dispersion is likely.

414 Currents may further disperse the fragments created by fishing gear or anchoring and 
415 the alga may settle and get established in a very distant location. Even in zones of

416 absolute protection within MPAs, where both fishing and anchoring are prohibited,

417 such fragments may arrive with currents from neighbouring sites with no such

418 restrictions. In addition, the ability of $C$. racemosa to reproduce sexually renders any

419 protection measures in MPAs inefficient to prevent the introduction of the species

420 from other locations.

422 Commercial fishing with nets is allowed in all management zones of NMPZ and in all

423 neighbouring areas with only a six-month ban in zone A; anchoring is permitted

424 within zone C. Due to the existence of the marine park and the developed eco-touristic

425 industry focusing on turtle-watching, there is an increased number of recreational

426 boats sailing in zones B and C and anchoring in zone C. As NMPZ is a semi-closed

427 bay, C. racemosa fragments that are produced within any of the protection zones are

428 likely to remain within the boundaries of NMPZ. Thus, the role of fishing gear and

429 recreational boats to the further spread of the species in NMPZ cannot be avoided by

430 the existing protection measures. The operation of NMPZ for the last eleven years did

431 not seem to decelerate the spread of C. racemosa in Laganas Bay. On the contrary, the

432 species is found in the NMPZ with very high probabilities of presence within

433 randomly placed $20 \times 20 \mathrm{~cm}$ quadrats on matte morte areas, rocky bottoms, and the

434 margins of P. oceanica meadows. For the reasons stated above (role of fishing gear

435 and anchoring, ability of sexual reproduction, further expansion of existing stolons)

436 no direct effect of the protection measures to the spread of the species is anticipated in

437 the future, unless the protection measures will prove effective to improve the status of

438 P. oceanica meadows within NMPZ (mainly because of the ban of anchoring and use

439 of mobile fishing gear) and thus reduce favourable microhabitats, such as patches 
440 within meadows. However, the process of sea grass recovery is very slow and no

441 short-term effects are likely. If the management measures prove ineffective to protect

442 the $P$. oceanica meadows in the park and fragmentation increases in the future, $C$.

443 racemosa will further spread covering all new matte morte areas.

445 Although the vulnerability of seagrass meadows to $C$. racemosa has been sufficiently 446 investigated, there is a lack of knowledge on the vulnerability of rocky bottoms. The 447 type of macroalgal assemblages (turf, encrusting, and erect) and the number of algal 448 species seem to affect the $C$. racemosa invasion, with substrates dominated by turfing 449 algae being more vulnerable (Ceccherelli et al., 2002). Turfs probably physically 450 assist the settlement of $C$. racemosa by entrapment of fragments of the alga and/or 451 enhancing the anchoring of stolons (Bulleri and Benedetti-Cecchi, 2008). However, 452 the extent of the invasion of $C$. racemosa on rocky bottoms, the invasion rates, 453 impacts to and competition with the benthic fauna, and the factors that favour 454 successful settlement and high densities are issues that need further investigation. As 455 found in this study, but also based on our personal observations in other areas of the 456 Ionian and the Aegean Sea, the extent of C. racemosa invasion on rocky habitats is 457 dramatic and the consequences largely unknown.

459 In conclusion: (1) we verified that vulnerability to $C$. racemosa invasion changes with 460 habitat and the most vulnerable habitat/substrate types are matte morte areas, the 461 margins of $P$. oceanica meadows, and rocky bottoms; (2) within fragmented 462 Posidonia oceanica meadows vulnerability differs among structural substrate types 463 and is higher along the margins of patches with no apparent dependence on patch size; 
464 and (3) the boundaries of the NMPZ do not seem to offer any protection against $C$.

465 racemosa invasion, which is explained by the dispersal mechanism of the species.

466

467

468 Acknowledgements

469 This study was part of the project "Survey of the Marine Benthic Fauna in the

470 National Marine Park of Zakynthos”, funded by EU and national sources

471 (coordinator: M.T.-L.). We thank the park authorities and staff for their valuable

472 assistance during the survey. We are grateful to three anonymous reviewers who made

473 valuable comments and suggestions that improved the quality of this paper.

474

475

476

477

478

480

481

482

483

484

485

\section{References}

Akaike, H., 1973. Information theory as an extension of the maximum likelihood principle, in: Petrov, B.N., Csaki, F. (Eds.), Proceedings of the Second International Symposium on Information Theory. Akademiai Kiado, Budapest, pp. 267-281.

Akaike, H., 1983. Information measures and model selection. Bulletin of the International Statistical Institute 44, 277-290.

Anscombe, F.J., 1950. Sampling theory of the negative binomial and logarithmic series approximations. Biometrika 37, 358-382.

Argyrou, M., Demetropoulos, A., Hadjichristophorou, M., 1999. Expansion of the macroalga Caulerpa racemosa and changes in soft bottom macrofaunal assemblages in Moni Bay, Cyprus. Oceanologica Acta 22, 517-528. 
489 Ashton, G., Boos, K., Shucksmith, R., Cook, E., 2006. Risk assessment of hull fouling 490 as a vector for marine non-natives in Scotland. Aquatic Invasions 1, 214-218.

491 Baldacconi, R., Corriero, G., 2009. Effects of the spread of the alga Caulerpa

492 racemosa var. cylindracea on the sponge assemblage from coralligenous

493 concretions of the Apulian coast (Ionian Sea, Italy). Marine Ecology 30, 337-345.

494 Boudouresque, C.F., Verlaque, M., 2002. Biological pollution in the Mediterranean

495 Sea: invasive versus introduced macrophytes. Marine Pollution Bulletin 44, 32-

$496 \quad 38$.

497 Boudouresque, C.F., Cadiou, G., Le Diréach, L., 2005. Marine portected areas: a tool

498 for coastal areas management, in: Levner, E., Linkov, I., Proth, J.M. (Eds.),

499 Strategic management of marine ecosystems. Springer, Dordrecht, The

$500 \quad$ Netherlands, pp. 29-52.

501 Buckland, S.T., Burnham, K.P., Augustin, N.H., 1997. Model selection: An integral

502 part of inference. Biometrics 53, 603-618.

503 Bulleri, F., Benedetti-Cecchi, L., 2008. Facilitation of the introduced green alga

$504 \quad$ Caulerpa racemosa by resident algal turfs: experimental evaluation of underlying

505 mechanisms. Marine Ecology Progress Series 364, 77-86.

506 Burnham, K.P., Anderson, D., 2002. Model selection and multi-model inference.

$507 \quad$ Springer, Berlin.

508 Ceccherelli, G., Piazzi, L., 2001. Dispersal of Caulerpa racemosa fragments in the

509 Mediterranean: Lack of detachment time effect on establishment. Botanica

$510 \quad$ Marina 44, 209-213.

511 Ceccherelli, G., Piazzi, L., Cinelli, F., 2000. Response of the non-indigenous

512 Caulerpa racemosa (Forsskål) J. Agardh to the native seagrass Posidonia 
oceanica (L.) Delile: effect of density of shoots and orientation of edges of meadows. Journal of Experimental Marine Biology and Ecology 243, 227-240.

515 Ceccherelli, G., Piazzi, L., Balata, D., 2002. Spread of introduced Caulerpa species in macroalgal habitats. Journal of Experimental Marine Biology and Ecology 280,

$1-11$.

518 Ceccherelli, G., Campo, D., Milazzo, M., 2007. Short-term response of the slow growing seagrass Posidonia oceanica to simulated anchor impact. Marine Environmental Research 63, 341-349.

Dean, C., Lawless, J.F., Willmot, G.E., 1989. A mixed Poisson-inverse Gaussian regression model. Canadian Journal of Statistics 17, 171-181.

Famà, P., Olsen, J.L., Stam, W.T., Procaccini, G., 2000. High levels of intra- and inter-individual polymorphism in the rDNS ITS1 of Caulerpa racemosa (Chlorophyta). European Journal of Phycology 35, 349-356.

Francour, P., Ganteaume, A., Poulain, M., 1999. Effects of boat anchoring in Posidonia oceanica seagrass beds in the Port-Cros National Park (north-western Mediterranean Sea). Aquatic Conservation: Marine and Freshwater Ecosystems $9,391-400$

Hastie, T.J., Tibshirani, R.J., 1990. Generalized Additive Models. Chapman and Hall,

535 Klein, J., Verlaque, M., 2008. The Caulerpa racemosa invasion: A critical review. Marine Pollution Bulletin 56, 205-225. 
537 Kružić, P., Žuljević, A., Nikolić, V., 2008. The highly invasive alga Caulerpa racemosa var. cylindracea poses a new threat to the banks of the coral Cladocora caespitosa in the Adriatic Sea. Coral Reefs 27, 441-441.

Lambert, D., 1992. Zero-inflated Poisson regression with an application to defects in manufacturing. Technometrics 34, 1-14.

Magri, M., Piazzi, L., Serena, F., 2001. La présence de Caulerpa racemosa le long des côtes septentrionales de la Toscane et les conséquences possibles sur l'activité de pêche, in: Gravez, V., Ruitton, S., Boudouresque, C.F., Le Direac'h, L., Meinesz, A., Scabbia, G., Verlaque, M. (Eds.), Fourth International Workshop on Caulerpa taxifolia. GIS Posidonie publ., Marseilles, France, pp. 338-344.

Martin, T.G., Wintle, B.A., Rhodes, J.R., Kuhnert, P.M., Field, S.A., Low-Choy, S.J., Tyre, A.J., Possingham, H.P., 2005. Zero tolerance ecology: improving ecological inference by modelling the source of zero observations. Ecology Letters 8, 1235-1246.

McCullagh, P., Nelder, J.A., 1989. Generalized Linear Models, second ed. Chapman and Hall, London.

553 Meinesz, A., 1999. Killer algae. University of Chicago Press, Chicago.

554 Milazzo, M., Badalamenti, F., Ceccherelli, G., Chemello, R., 2004. Boat anchoring on

558 Montefalcone, M., Chiantore, M., Lanzone, A., Morri, C., Albertelli, G., Bianchi, Mediterranean): effect of anchor types in different anchoring stages. Journal of C.N. 2008. BACI design reveals the decline of the seagrass Posidonia oceanica induced by anchoring. Marine Pollution Bulletin 56, 1637-1645.

Nizamuddin, M., 1991. The green marine algae of Libya. Elga Publisher, Bern. 
562 Panayotidis, P., Montesanto, B., 1994. Caulerpa racemosa (Chlorophyta) on the

563 Greek coasts. Cryptogamie Algologie 15, 159-161.

564 Panayotidis, P., Žuljević, A., 2001. Sexual reproduction of the invasive green alga 565 Caulerpa racemosa var. occidentalis in the Mediterranean Sea. Oceanologica $566 \quad$ Acta 24, 199-203.

567 Piazzi, L., Balata, D., 2009. Invasion of alien macroalgae in different Mediterranean 568 habitats. Biological Invasions 11, 193-204.

569 Piazzi, L., Ceccherelli, G., 2006. Persistence of biological invasion effects: Recovery 570 of macroalgal assemblages after removal of Caulerpa racemosa var. cylindracea. $571 \quad$ Estuarine, Coastal and Shelf Science 68, 455-461.

572 Piazzi, L., Ceccherelli, G., Cinelli, F., 2001. Threat to macroalgal diversity: effects of 573 the introduced green alga Caulerpa racemosa in the Mediterranean. Marine Ecology Progress series 210, 149-159.

Piazzi, L., Balata, D., Ceccherelli, G., Cinelli, F., 2005. Interactive effect of sedimentation and Caulerpa racemosa var. cylindracea invasion on macroalgal assemblages in the Mediterranean Sea. Estuarine, Coastal and Shelf Science 64,

579 R Development Core Team, 2008. R: A language and environment for statistical computing. R Foundation for Statistical Computing, Vienna, Austria. ISBN 3900051-07-0. http://www.R-project.org (Accessed 10 November 2008) allochthonous species: the case of Caulerpa taxifolia in the Ligurian Sea. ICES Journal of Marine Science 57, 1421-1427. 
585 Renoncourt, L., Meinesz, A., 2002. Formation of propagules on an invasive strain of Caulerpa racemosa (Chlorophyta) in the Mediterranean Sea. Phycologia 41, 533535.

Rigby, RA., Stasinopoulos, D.M., 2005. Generalized additive models for location, scale and shape. Applied Statistics 54, 507-554.

Rigby, R.A., Stasinopoulos, D.M., Akantziliotou, C., 2008. A framework for modelling overdispersed count data, including the Poisson-shifted generalized inverse Gaussian distribution. Computational Statistics and Data Analysis 53, 381-393.

Ruitton, S., Verlaque, M., Boudouresque, C.F., 2005. Seasonal changes of the introduced Caulerpa racemosa var. cylindracea (Caulerpales, Chlorophyta) at the northwest limit of its Mediterranean range. Aquatic Botany 82, 55-70.

Salomidi, M., Tsiamis, K., Katsanevakis, S., Issaris, Y., Panou, A., Zenetos, A., 2009. Invasion of the green alga Caulerpa racemosa in the Hellenic coasts. BIOLIEF, World Conference on Biological Invasions and Ecosystem Functioning, Porto,

601 Schaffelke, B., Hewitt, C.L., 2007. Impacts of introduced seaweeds. Botanica Marina $50,397-417$

603 Simberloff, D., 2000. No reserve is an island: marine reserves and nonindigenous species. Bulletin of Marine Science 66(3), 567-580.

605 Stasinopoulos, D.M., Rigby, R.A., 2007. Generalized additive models for location, 606 scale, and shape (GAMLSS) in R. Journal of Statistical Software 23, 1-46.

607 Streftaris, N., Zenetos, A., 2006. Alien marine species in the Mediterranean - the 100 608 'worst invasives' and their impact. Mediterranean Marine Science 7(1), 87-118. 
609 Tsiamis, K., Panayotidis, P., Zenetos, A., 2008. Alien marine macrophytes in Greece:

$610 \quad$ a review. Botanica Marina 51, 237-246.

611 Tsiamis, K., Montesanto, B., Panayotidis, P., Katsaros, C., Verlaque, M., 2010.

612 Updated records and range expansion of alien marine macrophytes in Greece

613 (2009). Medit Mar Sci 11(1), in press

614 Verlaque, M., Durand, C., Huisman, J.M., Boudouresque, C.F., Le Parco, Y., 2003.

615 On the identity and origin of the Mediterranean invasive Caulerpa racemosa

616 (Caulerpales, Chlorophyta). European Journal of Phycology 38, 325-339.

617 Verlaque, M., Afonso-Carrillo, J., Candelaria Gil-Rodríguez, M., Durand, C.,

618 Boudouresque, C.F., Le Parco, Y., 2004. Blitzkrieg in a marine invasion:

619 Caulerpa racemosa var. cylindracea (Bryopsidales, Chlorophyta) reaches the

620 Canary Islands (North-East Atlantic). Biological Invasions 6, 269-281.

621 Zenetos, A., Çinar, M.E., Pancucci-Papadopoulou, M.A., Harmelin, J.G., Furnari, G.,

622 Andaloro, F., Bellou, N., Streftaris, N., Zibrowius, H., 2006. Annotated list of

623 marine alien species in the Mediterranean with records of the worst invasive

624 species. Mediterranean Marine Science 6(2), 63-118 [2005].

625 Zenetos, A., Meriç, M., Verlaque, P., Galli, P., Boudouresque, C-., Giangrande, A.,

626 Çinar, M.E., Bilecenoğlu, M., 2008. Additions to the annotated list of marine

627 alien biota in the Mediterranean with special emphasis on Foraminifera and

628 Parasites. Mediterranean Marine Science 9(1), 119-165.

629

630 


\section{$631 \quad$ Figure captions}

632

633 Fig. 1: Map of the study area. The sampling sites and the protection zones of the

634 National Marine Park of Zakynthos are indicated.

635

636 Fig. 2: Location (representing three different substrate types) of C. racemosa frond 637 measurements within patches in fragmented $P$. oceanica meadows. Quadrats were 638 placed at the two intersections of the patch margin and the line (PM), within the $P$. 639 oceanica meadow at a $2 \mathrm{~m}$ distance from the margin of the patch (PO), and in two 640 randomly chosen spots within the patch $(\mathrm{Pa})$.

641

642 Fig 3: Estimated values of the two categorical variables (habitat type and zone) for 643 model $g_{6}$ of $C$. racemosa frond counts within $20 \times 20 \mathrm{~cm}$ quadrats. Graphs of the 644 mean response are given in the top panel and graphs of the standard deviation in the 645 bottom panel. Values are given in the response (log) scale and the corresponding 95\% 646 confidence intervals are indicated with dotted lines. MM: 'matte morte'; PM: margins 647 of P. oceanica meadows; PO: Posidonia oceanica meadows; R: rocky bottoms; S: 648 unvegetated sandy bottoms.

$650 \quad$ Fig. 4: Normal QQ plots for models $g_{6}$ (full model) and $g_{3}$.

652 Fig. 5: Estimated mean response and standard deviation of C. racemosa frond counts 653 in $20 \times 20 \mathrm{~cm}$ quadrats in relation to the levels of the categorical predictor variable 654 location, based on model $h_{4}$. Values are given in the response (log) scale and the 
655 corresponding 95\% confidence intervals are indicated with dotted lines. The three 656 levels of the predictor variable are defined in Fig. 2.

657 
Table 1: Survey 1: Summary of the parameterisation of the seven candidate models $g_{i}$ of the counts of $C$. racemosa fronds in $20 \times 20 \mathrm{~cm}$ plots.

\begin{tabular}{|c|c|c|c|c|c|c|}
\hline Model & $\begin{array}{l}\text { Modeled distribution } \\
\text { parameters }\end{array}$ & $\begin{array}{l}\text { Predictor } \\
\text { variables }\end{array}$ & df & AIC & $\Delta_{\mathrm{i}}$ & $\mathrm{w}_{\mathrm{i}}(\%)$ \\
\hline$g_{0}$ & - & Null & 2 & 2748.19 & 462.82 & 0.0 \\
\hline$g_{1}$ & $\mu$ & habitat & 6 & 2440.25 & 154.88 & 0.0 \\
\hline$g_{2}$ & $\mu$ & zone & 5 & 2744.40 & 459.03 & 0.0 \\
\hline$g_{3}$ & $\mu$ & habitat + zone & 9 & 2441.58 & 156.21 & 0.0 \\
\hline$g_{4}$ & $\mu, \sigma$ & habitat & 10 & 2285.39 & 0.03 & 49.7 \\
\hline$g_{5}$ & $\mu, \sigma$ & zone & 8 & 2712.07 & 426.70 & 0.0 \\
\hline$g_{6}$ & $\mu, \sigma$ & habitat + zone & 16 & 2285.37 & 0.00 & 50.3 \\
\hline
\end{tabular}


Table 2: Survey 2: Summary of the parameterisation of the seven candidate models $h i$ of the counts of $C$. racemosa fronds in $20 \times 20 \mathrm{~cm}$ plots in the second survey (patches in $P$. oceanica meadows).

\begin{tabular}{|c|c|c|c|c|c|c|}
\hline Model & $\begin{array}{l}\text { Modeled distribution } \\
\text { parameters }\end{array}$ & $\begin{array}{l}\text { Predictor } \\
\text { variables }\end{array}$ & df & AIC & $\Delta_{\mathbf{i}}$ & $\mathbf{w}_{\mathbf{i}}(\%)$ \\
\hline$h_{0}$ & - & Null & 2 & 825.01 & 56.21 & 0.0 \\
\hline$h_{1}$ & $\mu$ & location & 4 & 772.92 & 4.12 & 7.6 \\
\hline$h_{2}$ & $\mu$ & size & 3 & 826.80 & 58.00 & 0.0 \\
\hline$h_{3}$ & $\mu$ & location + size & 5 & 772.41 & 3.61 & 9.8 \\
\hline $\boldsymbol{h}_{4}$ & $\mu, \sigma$ & location & 6 & 768.80 & 0.00 & 59.6 \\
\hline$h_{5}$ & $\mu, \sigma$ & size & 4 & 828.21 & 59.41 & 0.0 \\
\hline$h_{6}$ & $\mu, \sigma$ & location + size & 8 & $\mathbf{7 7 0 . 7 1}$ & 1.91 & 23.0 \\
\hline
\end{tabular}


Table 3: Comparisons among different error distributions of the response variable (count of $C$. racemosa fronds in $20 \times 20 \mathrm{~cm}$ quadrats), based on the full models ( $g_{6}$ for survey 1 and $h_{6}$ for survey 2 ).

Model comparisons based on $\mathbf{g}_{6}$

\begin{tabular}{lcc}
\hline Distribution & df & AIC \\
\hline Negative Binomial & 16 & 2285.4 \\
Delaporte & 17 & 2287.3 \\
Sichel & 17 & 2336.4 \\
Poisson-inverse Gaussian & 16 & 2415.8 \\
Zero Inflated Poisson & 16 & 3083.9 \\
Poisson & 8 & 5067.3 \\
\hline
\end{tabular}

Model comparisons based on $h_{6}$

\begin{tabular}{lcc}
\hline Distribution & df & AIC \\
\hline Negative Binomial & 8 & 770.7 \\
Delaporte & 9 & 772.8 \\
Sichel & 9 & 778.0 \\
Poisson-inverse Gaussian & 8 & 839.8 \\
Zero Inflated Poisson & 8 & 916.8 \\
Poisson & 4 & 2249.2 \\
\hline
\end{tabular}




\section{ACCEPTED MANUSCRIPT}

Table 4: Survey 1: Expected counts of $C$. racemosa fronds in 20 x $20 \mathrm{~cm}$ quadrats, as predicted by model $g 6$.

\begin{tabular}{|c|c|c|c|c|}
\hline habitat type & zone A & zone B & zone $\mathrm{C}$ & zone Ia \\
\hline MM & $\begin{array}{l}13.5 \\
(9.1-20.1)\end{array}$ & $\begin{array}{l}14.1 \\
(10.7-18.6) \\
\end{array}$ & $\begin{array}{l}12.4 \\
(7.7-19.7) \\
\end{array}$ & $\begin{array}{l}7.9 \\
(5.0-12.3) \\
\end{array}$ \\
\hline PM & $\begin{array}{l}5.1 \\
(3.1-8.2) \\
\end{array}$ & $\begin{array}{l}5.3 \\
(3.2-8.7) \\
\end{array}$ & $\begin{array}{l}4.6 \\
(2.6-8.3) \\
\end{array}$ & $\begin{array}{l}2.9 \\
(1.7-5.2) \\
\end{array}$ \\
\hline $\mathrm{PO}$ & $\begin{array}{l}0.2 \\
(0.1-0.4)\end{array}$ & $\begin{array}{l}0.2 \\
(0.1-0.4)\end{array}$ & $\begin{array}{l}0.2 \\
(0.1-0.4)\end{array}$ & $\begin{array}{l}0.1 \\
(0.1-0.2) \\
\end{array}$ \\
\hline $\mathrm{R}$ & $\begin{array}{l}10.1 \\
(6.7-15.1) \\
\end{array}$ & $\begin{array}{l}10.5 \\
(8.2-13.5)\end{array}$ & $\begin{array}{l}9.2 \\
(5.6-15.0) \\
\end{array}$ & $\begin{array}{l}5.9 \\
(3.9-8.7) \\
\end{array}$ \\
\hline S & $\begin{array}{l}1.0 \\
(0.3-3.9)\end{array}$ & $\begin{array}{l}1.1 \\
(0.3-3.9)\end{array}$ & $\begin{array}{l}0.9 \\
(0.2-3.7)\end{array}$ & $\begin{array}{l}0.6 \\
(0.2-2.3)\end{array}$ \\
\hline
\end{tabular}




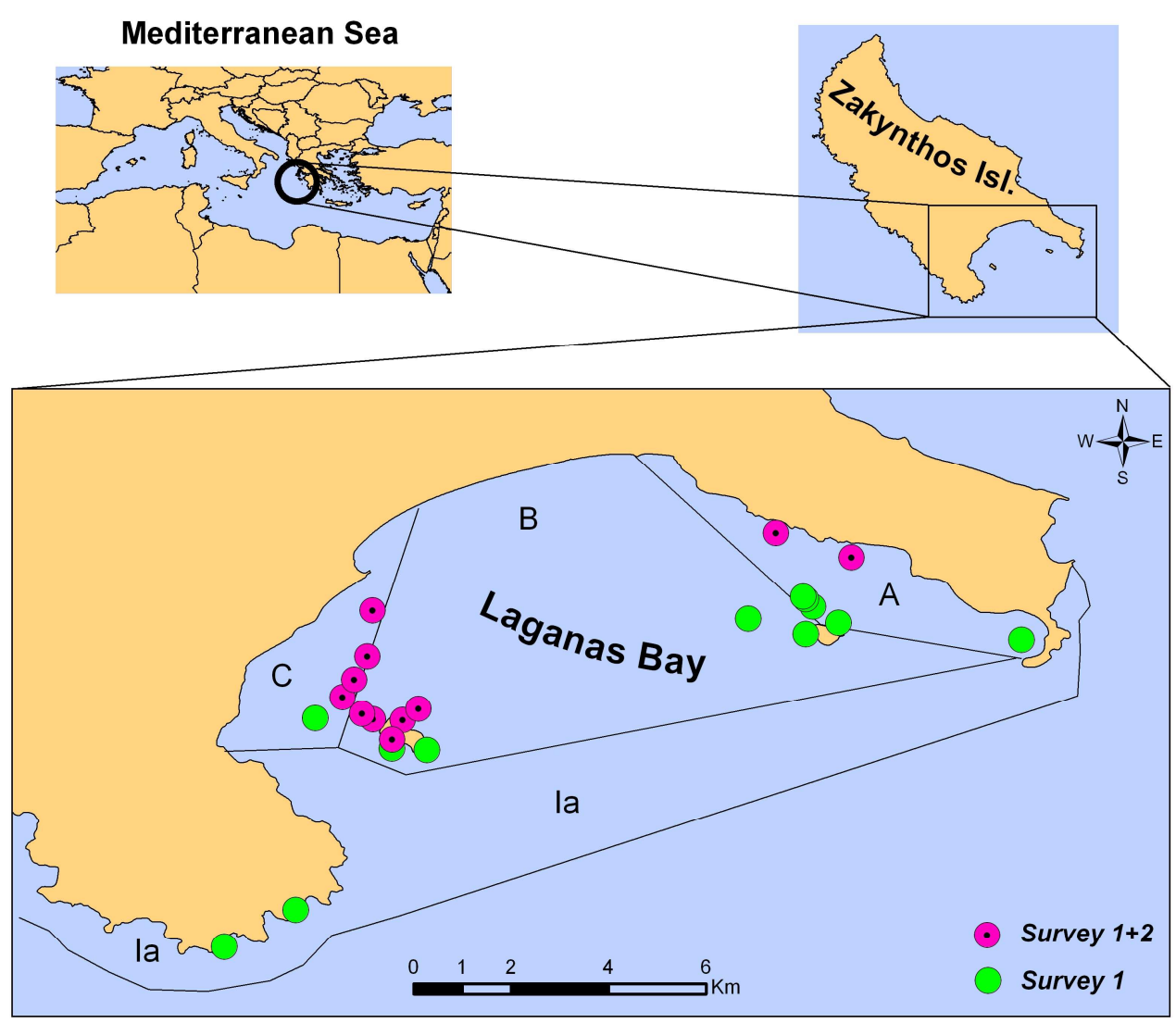




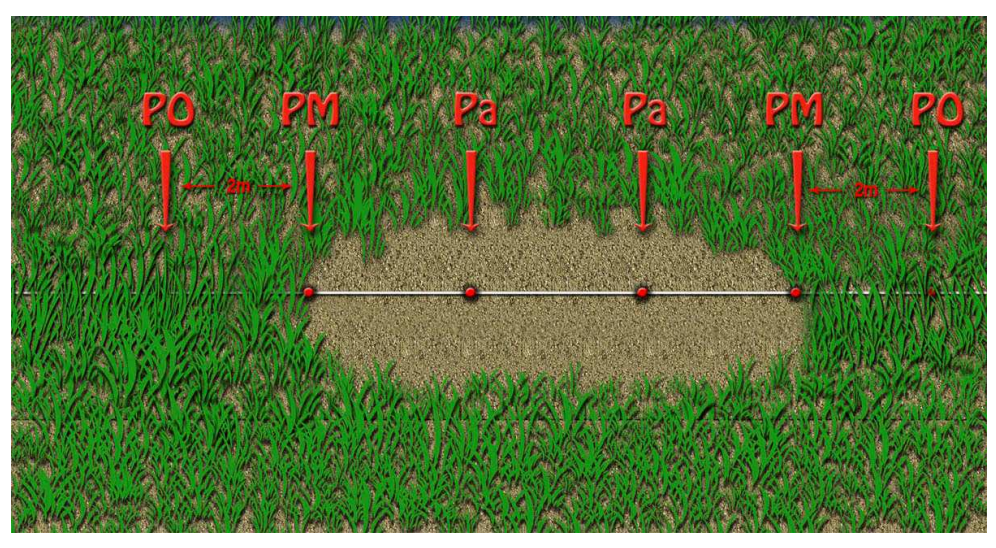




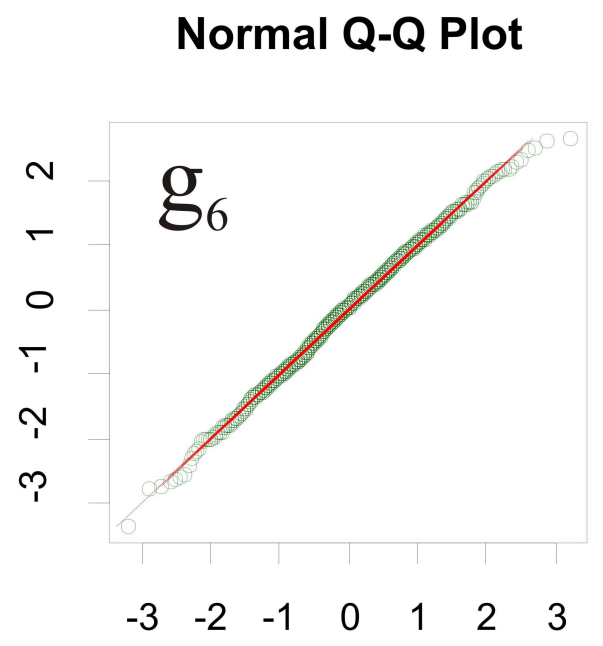

Theoretical Quantiles

\section{Normal Q-Q Plot}

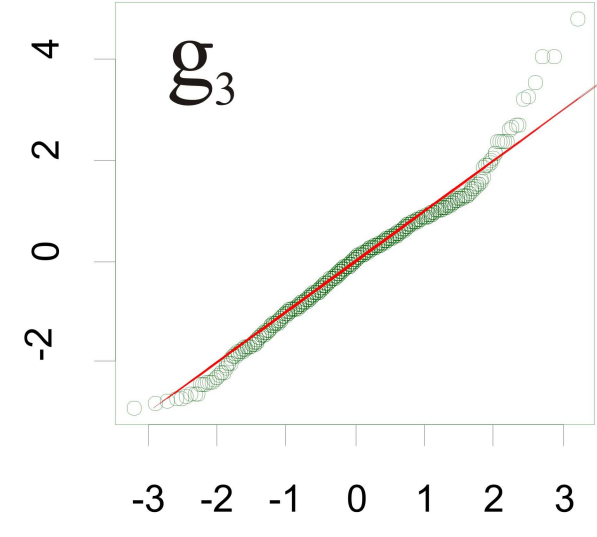

Theoretical Quantiles 
mean

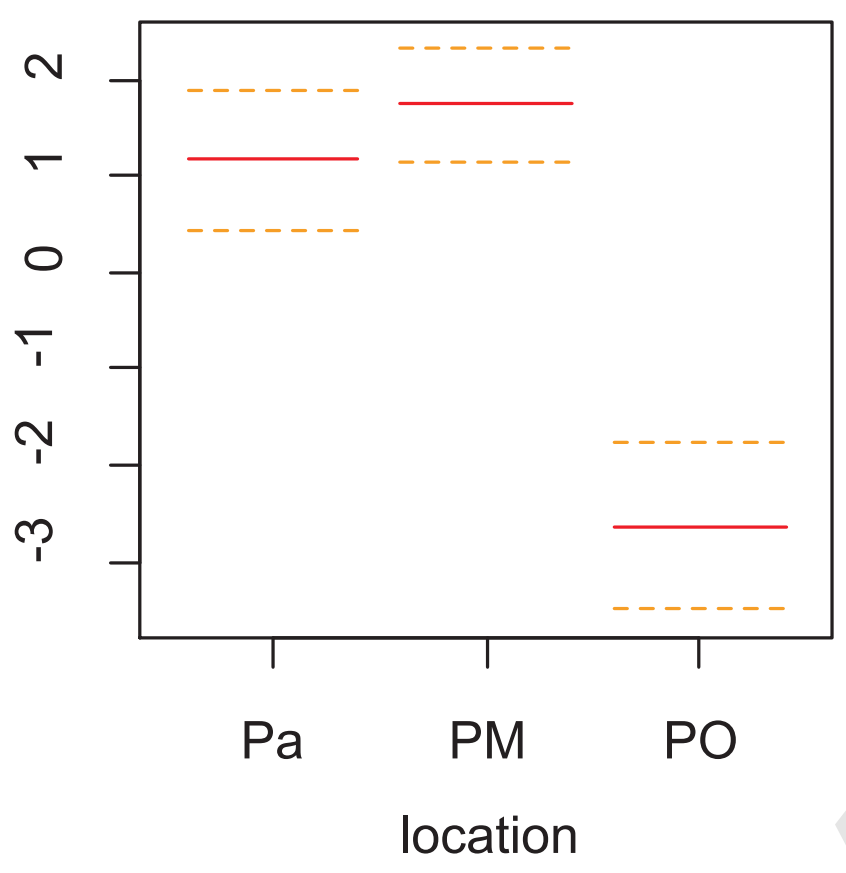

standard deviation

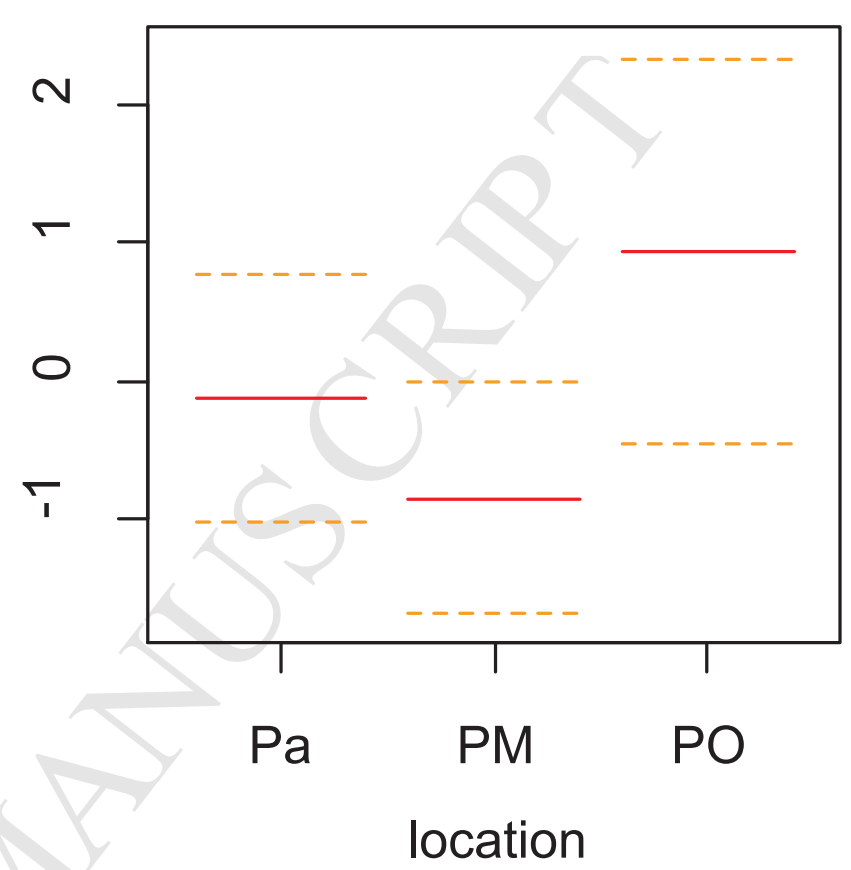

